\author{
Інна Червінська, \\ кандидат педагогічних наук, доцент кафедри \\ педагогіки початкової освіти, \\ ДВНЗ «Прикарпатський національний університет \\ імені Василя Стефаника» \\ (м. Івано-Франківськ, Україна) \\ Inna Chervinska, \\ $\mathrm{PhD}$ in Education, Associate Professor, \\ Department of Pedagogy of Primary Education, \\ Vasyl Stefanyk Precarpathian national university \\ (Ivano-Frankivsk, Ukraine) \\ chervinska.inna@gmail.com \\ ORCID ID 0000-0003-0745-1413
}

удк 373.013.3: 316.722 (23.0)

\title{
СОЦІОКУЛЬТУРНИЙ ПРОСТІР ГІРСЬКОЇ ШКОЛИ ЯК ІСТОРИЧНЕ, ЕТНОСОЦІАЛЬНЕ, ОСВІТНЬО-КУЛЬТУРНЕ ЯВИЩЕ ТА ПРЕДМЕТ НАУКОВИХ СТУДІЙ
}

\begin{abstract}
Анотація. У статті на основі цілісного ретроспективного аналізу наукової літератури, досвіду діяльності загальноосвітніх шкіл гірської місцевості регіону Українських Карпат увиразнено особливості соціокультурного простору гірської школи як історичного, етносоціального явища та предмета наукових студій. Вказано на те, що проблематика становлення, розвитку та проектування просторів є однією з тих, що найбільш активно розробляються в сучасній психолого-педагогічній літературі. У її рамках чітко виділяється й набуває самостійного статусу тематика еволюції регіональних соціокультурних просторів. Автором наголошується, що у філософських, культурологічних, психолого-педагогічних, соціологічних дослідженнях як фундаментальних, так і тих, які мають прикладний характер, термін «соціокультурний простір» використовується як вихідна категорія, оскільки розглядається як збірний образ, що вміщає все різноманіття існуючої реальності. Акцентується увага, що шляхом теоретичного аналізу джерельної бази та методологічного конструкту дослідження просторової тематики обґрунтовано сутність поняття «соціокультурний простір» як предмет історичних, етносоціальних, освітніх і культурологічних студій, окреслено теоретико-методологічні засади організації соціокультурного простору закладу загальної середньої освіти. Актуалізується використання таких методів дослідження як: пошуково-бібліографічний - 3 метою вивчення бібліотечних каталогів, бібліографічних видань; контент-аналіз - для з'ясування стану розробленості проблеми, формулювання терміносистеми базових понять і концептуалізації основних положень; аналіз змісту педагогічної діяльності закладів освіти, узагальнення власного досвіду співпраці з педагогами та учнями гірських шкіл.

Узагальнено, що просторовий розвиток та аналіз життєдіяльності людей, які проживають у певному соціокультурному просторі постають серед низки актуальних для сучасного суспільства питань. Педагогічна наука послуговується великою кількістю підходів та методів просторового аналізу, що дозволяють досліджувати соціальнопедагогічні проблеми та певною мірою сприяти їх ефективному вирішенню.
\end{abstract}

Ключові слова: соціокультурний простір, гірська школа, регіон Українських Карпат, етносоціальне явище, предмет наукових студій, регіональний вимір.

\section{SOCIO-CULTURAL SPACE OF THE MOUNTAIN SCHOOL AS A HISTORICAL, ETHNO-SOCIAL, EDUCATIONAL AND CULTURAL PHENOMENON AND SUBJECT OF SCIENTIFIC STUDIES}

\footnotetext{
Abstract. The article, based on a holistic retrospective analysis of scientific literature, the experience of secondary schools in the mountainous region of the Ukrainian Carpathians, to reveal the features of the socio-cultural space of the mountain school as a historical, ethnosocial phenomenon and subject of scientific studies.

It is pointed out that the issue of formation, development and design of spaces is one of those that are most actively developed in the modern psychological and pedagogical literature. Within its framework, the theme of the evolution of regional socio-cultural spaces is clearly distinguished and acquires an independent status. The author emphasizes that in philosophical, culturological, sociological research, both fundamental and applied, the term "socio-cultural space" is used as a source category that does not require additional theoretical argumentation, as a collective image that contains all the diversity of the existing reality.

Attention is emphasized that through the theoretical analysis of the source base and methodological construct of the sociocultural space of the mountain school the essence of the concept of "sociocultural space" as a subject of historical, ethnosocial, educational and culturological studies is substantiated.
} 
The use of such research methods as: search and bibliographic - in order to study library catalogs, bibliographic publications; content analysis - to clarify the state of development of the problem, the formulation of the terminology of basic concepts and conceptualization of the main provisions; analysis of the content of pedagogical activity of educational institutions, generalization of own experience of cooperation with teachers and students of mountain schools.

It is generalized that the spatial development and analysis of the life of people living in a certain socio-cultural space are among a number of the most pressing issues for modern society. Pedagogical science uses a large number of approaches and methods of spatial analysis, which allow studying socio-pedagogical problems and to some extent contribute to their effective solution.

Keywords: socio-cultural space, mountain school, region of Ukrainian Carpathians, ethnosocial phenomenon, subject of scientific studies, regional dimension.

Створення гармонійних відносин між людиною і соціокультурним простором може і повинно бути метою культурної політики держави.

В. Суртаєв

\section{ВСТУП}

Постановка проблеми. Проблема становлення, розвитку і життєдіяльності загальноосвітньої школи в гірській місцевості регіону Українських Карпат кінця XX - початку XXI століття набуває своєї значимості, перебуваючи впродовж останніх років у полі зору науковців, педагогів, представників громадськості, стимулюючись як зовнішніми викликами суспільства, так і внутрішніми суперечностями гірської спільноти, які зумовлені запитами місцевих жителів щодо кращого доступу закладів освіти до запропонованих державою освітніх ресурсів, матеріально-технічного обладнання й кадрового потенціалу та неспроможністю відповідного забезпечення в умовах гірського середовища всезростаючих потреб учнів до отримання якісних освітніх послуг та надання реальних можливостей для їх здобуття.

Дослідження історії української освітньої політики у галузі загальної середньої освіти у перші роки незалежності України переконує, що зміни її стратегічних цілей були наслідком зміни політичного курсу країни, що здобула суверенітет йобрала напрям на розбудову національної системи освіти. Збереження традиційних елементів побутової культури, діалектних особливостей, історико-культурної спільності, дотримання загальнолюдських цінностей, духовно-моральних засад у культурі етнографічних груп українців, які населяють регіон Українських Карпат, уможливлює інтеграцію різних етнічних культур та історії націотворення в системі освіти цього унікального за етнічним складом, освітньо-виховними традиціями, етнокультурною спадщиною регіону.

За останні десятиліття модернізація та реформування системи освіти України характеризується, з однієї сторони, - посиленням відповідальності регіонів за якість освіти і розвиток освітньої інфраструктури, а, з іншої, необхідністю її інтеграції в світовий освітній простір.

Проблематика становлення, розвитку та проектування просторів є однією з тих, що найбільш активно розробляються в сучасній психолого-педагогічній літературі. У ї̈ рамках чітко виділяється й набуває самостійного статусу тематика еволюції регіональних соціокультурних просторів. Проте роботи у вказаній царині наукових досліджень мали здебільшого пошуковий характер: йшло накопичення фактичного матеріалу, відкривалися особливості окремих регіональних освітніх просторів, виявлялися деякі закономірності та тенденції їх розвитку. На сьогодні з'явилися можливості досліджень концептуального характеру, що відображають реальну історію просторово-часових досліджень на їх сутнісно-концептуальному рівні.

Аналіз наукових досліджень і публікацій. Досяпти успіху в розкритті проблеми модернізації сучасної загальноосвітньої школи в гірській місцевості допоможе ґрунтовне вивчення, об'єктивна оцінка та творче осмислення кращих надбань національних і зарубіжних історико-педагогічних досліджень, науковою платформою яких прийнято вважати історіографію (Л. Березівська, В. Биков, Н. Гупан, О. Сухомлинська та ін.).

Відтак історію розвитку організації соціокультурного простору загальноосвітньої школи регіону Українських Карпат розглядаємо виходячи з досліджень учених, педагогів-практиків і культурно-громадських діячів минулого століття (І. Бажанський, О. Барвінський, С. Вінценз, І. Дощівник, С. Сірополко, С. Смаль-Стоцький, Ю. Федькович, І. Франко, Д. Хоров'юк та ін.) та наукових напрацювань з окресленої проблеми сучасних учених - О. Берладин, О. Будник, Т. Гавриленко, М. Євтух, В. Кузь, В. Мелешко, З. Онишків, О. Савченко, Р. Скульський, М. Стельмахович, О. Сухомлинська, Г. Філіпчук, В. Хрущ, М. Чепіль, Т. Янченко та інші. Історико-педагогічні та просвітницькі ретроспективи функціонування школи сільської місцевості досліджували С. Бричок, Г. Іванюк, В. Кравець, Г. Лемко, Г. Черненко, Г. Щука та ін. Увиразнення низки наукових напрацювань з окресленої проблеми (О. Біда, С. Бричок, Т. Гавриленко, П. Горбенко, М. Грищенко, Н. Гупан, П. Дроб'язко, Г. Іванюк, О. Коберник, В. Кузь, І. Курляк, О. Любар, В. Мелешко, Д. Пенішкевич) підтверджує наше узагальнення, що загальноосвітні школи гірської місцевості впродовж великого історичного періоду свого існування: від відкриття перших шкіл на теренах західноукраїнських земель й до тепер, реалізовують запити й потреби гірського соціуму (населення гірських сіл і містечок, гірських територіальних громад) щодо забезпечення дітей та молоді відповідним рівнем освіти за місцем їх основного проживання.

МЕТА I ЗАВДАННЯ ДОСЛІДЖЕННЯ - на основі цілісного ретроспективного аналізу наукової літератури, досвіду діяльності загальноосвітніх шкіл гірської місцевості регіону Українських Карпат, розкрити особливості соціокультурного простору гірської школи як історичного, етносоціального явища та предмета наукових студій.

МЕТОДИ ДОсЛІДЖЕНнЯ: пошуково-бібліографічний - 3 метою вивчення бібліотечних каталогів, бібліографічних видань; контент-аналіз - для з'ясування стану розробленості проблеми, формулювання терміносистеми базових понять і концептуалізації основних положень; аналіз змісту педагогічної діяльності освітніх закладів, узагальнення власного досвіду співпраці з педагогами та учнями гірських шкіл. 


\section{РЕЗУЛЬТАТИ ДОСЛІДЖЕННЯ}

Вивчення проблеми історіографії дослідження організації соціокультурного простору загальноосвітньої школи в гірській місцевості наприкінці XX - початку XXI століття як освітньо-соціального феномену, одного з основних джерел національного відродження та забезпечення культурно-історичних традицій українського народу, дає змогу краще усвідомити освітні, виховні, етнокультурні надбання цього самобутнього регіону, особливості організації педагогічного процесу та освітньої діяльності педагогів, що зумовлені поєднанням низки історико-культурних, соціально-економічних та освітньо-просвітницьких чинників з метою виокремлення концептуальних підходів до його розвитку.

у філософських, культурологічних, соціологічних дослідженнях як фундаментальних, так і тих, які мають прикладний характер, термін «соціокультурний простір» використовується як вихідна категорія, яка не потребує додаткової теоретичної аргументації, як збірний образ, що вміщає все різноманіття існуючої реальності. У цьому контексті для нас цікавою є думка В. Стьопіна, який зокрема наголошує на тому, що «міждисциплінарні науки це науки, в яких застосовується понятійні засоби і методи, які вироблені в різних дисциплінах і синтезуються в новій науці для вирішення її специфічних завдань. Трансдисциплінарність - це характеристика однієї з мов науки» (Стьопін В., 2007, с. 97).

Питання просторового розвитку та аналізу постають серед низки найактуальніших для сучасного суспільства проблем. Педагогічна наука послуговується великою кількістю підходів та методів просторового аналізу, що дозволяють досліджувати соціально-педагогічні явища та певною мірою сприяти їх ефективному вирішенню. Відтак, особливу зацікавленість викликає аналіз розгортання соціокультурних процесів у системі освіти, осмислення ролі й місця освіти, культури і соціуму у формуванні особистості, зв'язок соціокультурних явищ і природного середовища, розгляд системи ціннісних орієнтацій різних соціальних та етнічних груп, які населяють регіон Українських Карпат.

Таким чином, можна стверджувати, що в контексті сучасних трансформацій та освітніх реформ значно зросла зацікавленість спільноти й фахівців освітньої галузі проблемами просторових характеристик освіти як соціального інституту, як громадського та особистого добробуту особливого типу та структури та до більш ширшого осмислення діяльності різних суб'єктів освітньої сфери, до міждисциплінарного обговорення перспектив модернізації національної освітньої системи.

Описані методологічні позиції дослідників відносно співвідношення сутності понять «простір», «середовище», визначення їх змістових характеристик та функціонального призначення терміну «соціокультурний простір», дозволяють розглядати соціокультурний простір закладу освіти як специфічну просторово-часову домінанту, що виступає як результат функціонування освіти і культури у взаємодії з визначеними соціальними параметрами його становлення та розвитку.

Соціокультурний простір - багатоаспектне і багаторівневе явище, що не може обмежуватися його вивченням лише в контексті вузькоспеціального наукового напрямку. Складність теоретичного узагальнення і практичного застосування вказаного поняття полягає в неоднозначності його трактувань і застосуванні в різних наукових галузях із врахуванням різних методологічних підходів (Тельманова А., 2014).

Як конгломерат громадської і культурної характеристик певного регіону соціокультурний простір розглядається в історичному, етносоціальному, культурному й освітньому ракурсі наукового знання. Оскільки включення різних соціокультурних явищ у простір регіону необхідно здійснювати із врахуванням загально-філософських психологопедагогічних позицій до визначення поняття простору. Зазначені характеристики підтверджують тезу про багатовимірність соціокультурного простору, до якого входять ареали багатьох культур та соціокультурні простори регіонів з їх автентичним наповненням.

Термін «соціокультурний простір» у сучасній науково-педагогічній, філософській та культурологічній літературі зустрічається досить часто. Активний дослідницький інтерес до визначеної проблематики, на думку В. Цукермана, пояснюється «евристичними можливостями, які полягають в аналізі цього феномена в умовах складного переплетіння процесів глобалізації та регіоналізації, універсалізації сучасного соціуму і різноманітності його локальних проявів» (Цукерман В., 2009). Інакше кажучи, вказана категорія виявляється формою, яка вміщує в собі і структурує все різноманіття панівних на сьогоднішній день підходів до опису та визначення сутності освітніх, соціальних і культурних змін. Правомірність застосування зазначеного терміну багато вчених пояснюють ще й фактом неможливості дослідження соціальної реальності у відриві від стану розвитку освіти, культурних надбань та історичних подій і навпаки.

У сучасному науково-педагогічному дискурсі активно використовується поняття «соціокультурний простір», однак зазвичай без конкретизації сутності та операційних складників цього поняття. Проте активне використання цього терміну в управлінській діяльності, освітньому менеджменті, освітньо-виховних практиках (соціокультурний простір управління, соціокультурний простір закладів вищої освіти та ін.) вкотре підтверджує, що поняття «простір» та його дефініції, ускладнені змістовим наповненням, входять до наукового тезаурусу сучасних учених та професійної лексики педагогів, оскільки вони розкривають сутність реальних педагогічних явищ та процесів. Вивчення соціокультурного простору $€$ інтегральним завданням філософії, історії, соціології, культурології, психології, педагогіки, географії, антропології та інших суспільствознавчих дисциплін. Кожна наука, опираючись на предмет дослідження, має наукову мету та завдання наукового пізнання і відповідно формує свій науково-методологічний апарат, який дозволяє вирішувати поставлені завдання та проблеми, що виникають як у процесі трансформацій самого об'єкта дослідження - соціокультурного простору, так і наукового пошуку.

Зміст і специфіку соціокультурного простору визначають близькі до нього, але самодостатні у своїх проявах, категорії «соціальний простір», «освітній простір» і «культурний простір». Певною мірою ці категорії можуть служити 
відправними точками для розуміння досліджуваного явища. Однак варто зауважити, що проблема визначення соціокультурного простору пов'язана, перш за все, з тим, що в науковому дискурсі досі не склалося чіткої позиції щодо тлумачення результатів взаємодії соціального і культурного просторів.

Ураховуючи запропоновані наукові концепції й погляди (В. Слободчикова, І. Шендрика, І. Фрумін, та ін.) на соціокультурний простір та його структуру, можемо стверджувати про існування зазначеного типу простору, який знаходиться на межі соціального, освітнього, культурного та географічного просторів.

Наукова рефлексія дослідження спрямована на осмислення того, наскільки автентичні ціннісні надбання регіональної культури визначають реальний стан та динаміку розвитку простору культури й освіти Українських Карпат - цієї самобутньої за всіма ознаками та характеристиками території, яку ще в минулому столітті прагнула глибше вивчити та розкрити феномен її унікальності ціла плеяда науковців: Станіслав Вінценз «На високій полонині» (1936), Раймунд Фрідріх Кайндль «Гуцули: їхнє життя, звичаї та народні перекази» (1894, 2003), Марія Лаврук «Гуцули Українських Карпат (етнографічне дослідження) (2005), Михайло Ломацький «Заворожений світ» (2014), Мартін Поллак «До Галичини» (1984) та ін.

Досить тривалий період поняття «соціокультурний простір» як цілісна дефініція не розглядалося дослідниками педагогіки. Проте це поняття було ключовим у соціології, філософії та культурології. Зазначене дає підстави стверджувати, щодо феномена соціокультурності в часо-просторовому дискурсі провідних ідей педагогіки, соціології і філософії XXI ст., а щодо предмета дослідження його просторових характеристик з позицій філософії, й досі тривають наукові полеміки та дискусії. Оскільки простір був описаний у соціології, географії, психології, педагогіці, релігієзнавстві, культурології крізь призму визначення діяльності закладу загальної середньої освіти як соціокультурний феномен і передбачає, крім трансцендентної складової, матеріальний світ, що охоплює сукупність різних складових компонент, видів, типології, напрямів та течій, яким властива просторово-часова еволюція.

Соціокультурний простір також виступає як просторово-часовий континуум, відповідно у порівнянні з культурним простором, має більш повний, багатофакторний і багатовимірний прояв реальності, з їі відображенням через розкриття змісту відповідної категорії. На переконання С. Храпова, «соціокультурний простір - це інтегральний феномен, що поєднує ключові параметри соціального і культурного розвитку суспільства. Його слід розглядати з позицій змісту і структури» (Храпов С., 2011, с. 15).

Поняття «соціокультурний простір» відображає взаємозв'язок та взаємовплив умов, що забезпечують розвиток людини, але в цьому випадку передбачається ї̈̈ присутність у просторі, де здійснюється взаємовплив, взаємодія оточення з суб'єктом.

Увиразнення соціокультурного простору, як історичного, етносоціального та освітньо-культурного явища, дає підстави розуміти його як багатовимірний простір, який організований відносно сучасних потреб соціуму й відповідає інноваційним тенденціям освітньо-виховного, культурно-просвітницького, етнічно-історичного розвитку освітнього закладу гірської місцевості регіону Українських Карпат. Відтак актуалізується необхідність дослідження історіографії та джерельної бази дослідження.

Основу розгляду проблеми організації соціокультурного простору загальноосвітньої школи в гірській місцевості регіону Українських Карпат складають ідеї системоутворюючого процесу, пов'язаних із формуванням національної, регіональної (як локальної, так і загально-цивілізаційної) та загальнолюдської складової, яку доповнюють, або диференціюють різні категорії духовно-ціннісних вимірів, «коли різні оцінки культурних цінностей не слугуватимуть відцентровим процесам, а, відштовхуючись від принципів об'єктивності, розглядатимуться в концепції рівноцінного розвитку різноманітних культурних вимірів українських історикопедагогічних реалій» (Сухомлинська О., 2007, с. 48-49).

Тобто, предмет наукової розвідки щодо становлення і розвитку соціокультурного простору закладу освіти, закономірності функціонування освітніх регіональних систем або компонентів освітньої сфери, які склалися внаслідок просторової неоднорідності прояву різних груп чинників, складає соціально-економічні, культурні, етнічні та інші важливі показники сталого розвитку регіону Українських Карпат. Саме таке окреслення його змістового контенту відображає його регіональні аспекти.

Предметом наукових студій виступає соціокультурний простір гірської школи регіону Українських Карпат, формування культурного та освітнього простору якого базується на історично накопиченому та сформованому у процесі життєдіяльності, багатому етнокультурному досвіді, унікальній самобутності культурної спадщини та вікових традиціях, надбаннях народної педагогіки. Дослідження соціокультурного простору реалізується шляхом інтерпретації специфічних показників гірського середовища, етнокультурних традицій, специфіки менталітету місцевих жителів 3 використанням методики аналізу соціокультурного портрета регіону. Умови, методи і проблеми його формування у в сучасних реаліях виступають одним із важливих завдань культури, оскільки безпосередньо визначають загальні тенденції розвитку державної внутрішньої і зовнішньої політики, економічних умов функціонування громадських інститутів, інтелектуального і емоційного стану всіх верств населення.

У контексті наукового дискурсу важливо зрозуміти яким чином на процес становлення та розвитку соціокультурного простору загальноосвітньої школи в гірській місцевості впливає розвиток соціального піклування, взаємопроникнення між соціальними відносинами та культурою, то в нашому дослідженні ми використовуємо поняття «соціокультурний простір закладу загальної середньої освіти» в інтерпретації представників соціокультурного та середовищного підходів, які сформувалися в соціально-філософській та психолого-педагогічній думці кінця XX століття (А. Ахієзер, С. Кірдіна, М. Лапін С. Макеєва, В. Стьопін та ін. Оскільки у цьому понятті, на думку М. Лапіна, 
відбувається інтеграція трьох специфічних форм багатомірного буття людини, втілених, по-перше, у взаємодії людини з суспільством, по-друге, у характері культури, по-третє, у типі соціальності (Лапін М., 2000, с. 3-4).

Проблема соціокультурного простору з точки зору характеристик його сутності, структури, функцій та цілісності за останні роки стала об'єктом розгляду міждисциплінарного аналізу представників різноманітних напрямів наукового знання. Така зацікавленість просторовою тематикою зумовлена поширенням глобалізаційних процесів, а також у зв'язку з евристичним потенціалом поняття, який полягає у структурному аналізі цього феномену за умов складних дифузійних процесів: глобалізації, регіоналізації, універсалізації. Використання терміну «соціокультурний простір» $€$ певною альтернативою традиційному понятійно-термінологічному тезаурусу та показником відповідного рівня педагогічного знання, переходу України до відкритого діалогу зі світом, її входження у світовий соціокультурний простір. Представники соціогуманітарної думки (Т. Заславська, М. Лапін, Т. Шанін та ін.) дійшли висновку, що зміна соціокультурного простору супроводжується появою нових смислів, які віддзеркалюють багатоманітну ситуативність суспільного буття та змістовність людської життєдіяльності з певним чином залежними від них соціальними конструктами подій та явищ навколишньої дійсності, соціалізації сучасного соціуму та варіативності проявів його локалізації.

Для ґрунтовного вивчення проблеми 3 історико-педагогічних позицій та регіональних підходів, нами виокремлено ґенезу цього неоднозначного явища. Оскільки з огляду на специфіку розкриття просторової тематики з певними акцентами на регіональні виміри, відсутність її цілісного дослідження, праці з історіографії, наукова періодика, кіноархіви та інші джерела можуть складати основу наукового пошуку, сприяти розкриттю провідних стратегій розвитку загальноосвітніх закладів гірської місцевості та механізмів організації на їх базі автентичного соціокультурного простору, сприятливого для інтелектуального й творчого особистісного розвитку учнів та саморозвитку й професійного зростання педагогів.

Спроби багатьох країн Європи побудувати єдиний глобальний соціокультурний простір стикаються з певним опором та низкою перешкод щодо реалізації цього мультикультурного проєкту, позаяк від початку XXI століття все більшої популярності та поширення набирає зворотний процес, пов'язаний із вивченням регіональних і локальних особливостей соціокультурного простору певних територій. Категорія простору у сучасній гуманітарній науці набуває характеру метафори, за допомогою якої описуються різноманітні «простори» та «середовища» як у фізичній протяжності, так і в її ментальній або ж віртуальній сутності (Бачинська Є., 2007). Однак тут криється певна методологічна небезпека, оскільки лише аналіз змістового наповнення вказаної категорії зазвичай не дозволяє різнобічно та цілісно описати це різнопланове соціально-культурне явище, чітко визначити його межі, дати розгорнуті характеристики. Поряд з цим - саме дефініція «простір» $є$ найбільш придатною до опису феноменів, які мають якісні характеристики протяжності, осмисленості та представництва.

Проблемою регіонів завжди був тотальний адміністративний контроль, об'єднання і централізація за часів панування тоталітарного режиму, які хоч і стримували розвиток цілих територій та окремих населених пунктів, які розташовані у високогірних, віддалених від адміністративних центрів регіонах, але завдавали значної шкоди збереженню їх автентичності. Оскільки специфічне природно-географічне середовище, складні кліматичні умови, багата етнокультурна спадщини, різноманітний етнічний склад, унікальність історичних традицій, впливають на самобутність життєдіяльності місцевого населення, визначать його духовні та ціннісні орієнтири, формують відповідні психотипи (степовий романтик, відважний горянин, залюблений у море тощо). Всі названі чинники мають значний вплив на формування оригінальної системи освіти регіону.

Незважаючи на широке використання в науковій літературі, поняття «соціокультурний простір» має досить слабке теоретичне обґрунтування. У філософських, культурологічних, соціологічних дослідженнях, як фундаментальних, так і тих, які мають прикладний характер, термін «соціокультурний простір» використовується як вихідна категорія, що не потребує додаткової теоретичної аргументації, як збірний образ, що вміщає все різноманіття існуючої реальності.

Вивчаючи специфіку соціокультурного простору, Б. Мосальов відзначає, що в ньому «живуть» і взаємодіють різні культурні традиції, зразки, культурні смисли, цінності, інновації. Він уважає, що «... змістовну спрямованість часу в багатьох аспектах задає соціокультурний простір. Під простором слід розуміти відносини протяжності й співіснування, які виникають у процесі життєдіяльності людини. Просторовий аспект культурного різноманіття постає в масштабах людства, суспільства, нації, регіону, різних соціальних спільнот» (Мосальов Б., 1998, с. 24).

Дещо розширений та узагальнений перелік змістових характеристик соціокультурного простору пропонує дослідниця Н. Крилова: динаміка розвитку освіти (темп і масштаб створення закладів освіти); доступність освіти (враховуються спосіб життя населення і культурно-освітні запити, рівень добробуту, територіальне розташування закладів освіти); етнокультурний характер (можливість підтримання національної культури, традицій, норм, цінностей); практико-трудова спрямованість (трудові відносини, які виникають у просторі); спадкоємність освіти (можливість ї̈̈ здобуття та продовження впродовж життя) (Крилова Н., 1995).

Зазначені підходи та їх узагальнення дають підстави характеризувати соціокультурний простір загальноосвітньої школи гірської місцевості за такими психолого-педагогічними показниками як: комфортність і відкритість простору, розвиваючий і творчий характер простору, простір соціально-освітнього партнерства та взаємодії, простір організованого дозвілля, здоров'язбережувальний простір, простір музеєзнавства та мистецтвознавства, профорієнтаційний простір. Це сприяє тому, що соціокультурний простір набуває дещо ширших характеристик, пов'язаних із його творчо-розвиваючим впливом на формування особистості, динамічністю виховних впливів та суспільних характеристик. Оскільки сам зміст поняття «простір освіти» розглядається сьогодні з дещо інших позицій і набуває актуальності завдяки руйнуванню міжнаціональних культурних кордонів. На межі розуміння освіти 
вже як феномену життєдіяльності ї̈ зміст максимально розширюється, не втрачаючи при цьому своєї цілісності. Соціокультурний простір за таких обставин стає механізмом інноваційних змін, які потребують систематизації.

Увиразнення джерельної бази (сукупність дібраних, систематизованих і класифікованих джерел) як носія інформації про педагогічне минуле, проведений історико-педагогічний аналіз науково-педагогічної літератури, вивчення нормативно-правових актів, які стосуються освітньої галузі, вивчення основоположних підходів щодо періодизації розвитку української педагогічної думки, дозволив виокремити певні періоди у розвитку системи освіти, дотичні до проблеми нашого дослідження.

\section{ВИСНОВКИ ТА ПЕРСПЕКТИВИ ПОДАЛЬШИХ ДОСЛІДЖЕНЬ}

На підставі узагальнення матеріалів досліджень науковців, присвячених просторовій проблематиці, нами узагальнено, що термін «соціокультурний простір» утворився шляхом інтеграції понять соціальний, культурний й освітній та зумовлений необхідністю взаємного співвіднесення соціальних і освітньо-культурних характеристик явищ, які володіють внутрішньою єдністю всіх зазначених елементів і властивостей з різноманітними зв'язками та відносинами. Увиразнення різних підходів, щодо формулювання поняття «соціокультурний простір освітнього закладу» дає нам можливість трактувати соціокультурний простір загальноосвітньої школи гірського регіону як «сукупність духовно-матеріальних, управлінсько-організаційних умов, що забезпечують розвиток та саморозвиток вільної й активної особистості, з метою реалізації її творчого потенціалу та функціонування просторових об'єднань суб'єктів освіти на професійних засадах».

Встановлено, що вивчення соціокультурного простору освітнього закладу в кінці XX на початку XXI ст. здійснювалося крізь призму націотворення та державотворення, суспільних трансформацій та освітніх реформ. За визначених умов соціокультурний простір розглядається як історичне та етнокультурне явище, яке пов'язано з перебудовчими процесами в системі освіти України. У цей період проходить становлення різних видів освітніх середовищ (просторів) закладів загальної середньої освіти, які формуються із врахуванням інформаційнокомунікаційного та освітньо-культурного контекстів, шляхом надання пріоритетності національним цінностям, свободі й творчості, толерантності та гуманізму.

Перспективи подальших наукових розвідок пов'язуємо з вивченням ефективних механізмів організації соціокультурного простору в умовах суспільних трансформацій.

\section{СПИСОК ВИКОРИСТАНИХ ДЖЕРЕЛ}

Бачинська, Є. (2017) Вектори змін методичної роботи в закладах загальної середньої освіти в контексті реформування освіти в Україні. Народна освіта. Вип. 3. С. 16-21.

Крилова, Н. (1995). Социокультурный контекст образования. Новые ценности образования. Вып. 2. М., 110 с.

Лапин, Н. И. (2000). Социокультурный подход и социетально-функциональные структуры. Социол. исследования. № 7. С. 3-12.

Мосалев, Б. Г., (1998). Социокультурное многообразие: Опыт целостного осмысления Москва: МГУК. 168 с.

Степин, В. С. (2007). О философских основаниях синергетики.Синергетическая парадигма. Синергетика образования. М.: ПрогрессТрадиция. С. 96-102.

Сухомлинська, О. (2005). Історико-педагогічне дослідження та його «околиці» Шлях освіти. № 4. С. 43-47.

Сухомлинська, О. (2007). Методологія дослідження історико-педагогічних реалій другої половини XX століття. Шлях освіти. № 4. C. 6-9

Тельманова, А. С. (2014). Проблемы дефиниции социально-культурного пространства. Вестник Кемеровского государственного университета культуры и искусств, (29-1), 149-155.

Храпов, С. А. (2011). Трансформация общественного сознания в социокультурном пространстве: автореф. дис. на соиск. учен. степ. д-ра филос. наук : 09.00.11 / Храпов Сергей Александрович ; Рос. гос. соц. ун-т. М. 39 с.

Цукерман, В. С. (2009). Единое социокультурное пространство: аспекты рассмотрения. Вестн. Челяб. гос. академии культуры и искусств. № 2 (18). С. $49-55$.

\section{REFERENCES}

Bachynska, Y. (2017) Vectors of changes in methodological work in general secondary education institutions in the context of education reform in Ukraine. Public education. Vip. 3. pp. 16-21.

Krylova, N. (1995). Sociocultural context of education. New values of education. Issue. 2. M., 110 p.

Lapin, N. (2000). Sociocultural approach and socio-functional structures. Sociol. research. № 7. pp. 3-12.

Mosalev, B. (1998). Socio-cultural diversity: The experience of holistic thinking Moscow: Moscow State University. $168 \mathrm{pp}$

Stepin, V. (2007). On the philosophical foundations of synergetics. Synergetic paradigm. Synergetics of education. M.: Progress-Tradition. pp. 96-102.

Sukhomlinska, O. (2005). Historical and pedagogical research and its "surroundings" The way of education. № 4. pp. $43-47$.

Sukhomlynska, O. (2007) Methodology of research of historical and pedagogical realities of the second half of the XX century The way of education. № 4. pp. 6-9

Telmanova, A. (2014). Problems of definition of socio-cultural space. Bulletin of the Kemerovo State University of Culture and Arts, (29-1), pp.149-155.

Khrapov, S. (2011). Transformation of public consciousness in sociocultural space: author's ref. dis. on soisk. scientist. steppe. Dr. Philos. Sciences: 09.00.11 / Khrapov Sergey Alexandrovich; Ros. state soc. un-t. M. 39 p.

Zuckerman, V. (2009). Unified socio-cultural space: aspects of consideration. Vestn. Chelyabinsk. state Academy of Culture and Arts. № 2 (18). pp. 49 -55.

Статтю подано до редколегії 28.09.2020 p.

Рекомендовано до друку $\quad 17.10 .2020$ р. 